\title{
Public spaces and religion: an idea to debate, a monument to analyze
}

Espaços públicos e religião: uma ideia para debater, um monumento para analisar

\author{
Emerson Giumbelli ${ }^{\star}$ \\ *Universidade Federal do Rio Grande do Sul - Porto Alegre, RS, Brasil \\ emerson.giumbelli@yahoo.com.br
}




\begin{abstract}
The text presents the first results of a study conducted in Brazil about the construction of a monument that represents a Catholic saint. The analysis is developed in two planes. One focuses on discourses that constitute something as "public". The other focuses on spatial dimensions: how material features influence configurations of public spaces. Each theoretical exploration corresponds to an analysis of certain facets of the monument, which are respectively related to the debates that it has triggered and the architectural solutions generated. The articulation between these two dimensions is inspired by thematizations and debates about what is public art. The aim is to contribute to the theoretical discussion and the empirical analysis of situations involving the presence of religion in public spaces.
\end{abstract}

Keywords: monuments; secularism; space; public sphere.

\title{
Resumo
}

O texto apresenta resultados de uma pesquisa no Brasil acerca da construção de um monumento que representa uma santa católica. A análise se desenvolve em dois planos. Em um deles, a atenção recai sobre os discursos que constituem algo como público. No outro, o que está em foco é a dimensão espacial: como composições materiais impactam configurações de espaços públicos. A cada exploração teórica corresponde uma análise de certas facetas do monumento, ligadas, respectivamente, aos debates que suscita e às soluções arquitetônicas que mobiliza. A articulação entre essas duas dimensões inspira-se em elaborações e debates acerca do que seja arte pública. Pretende-se assim dar uma contribuição para a discussão teórica e a análise empírica de situações que envolvem a presença da religião em espaços públicos.

Palavras-chave: monumentos; catolicismo; espaço público; laicidade. 


\section{Introduction $^{1}$}

In 1992, Jewish studies professor James Young analyzed three public works that he considered "counter-monuments". The works were conceived in the late 1980s in Germany with the common objective of thematizing the memory of the Nazi period. The idea was not to celebrate something, which is the role commonly attributed to monuments, but to reflect on history. The concrete results of this idea are "counter-monuments" that dialog with a strong trend in contemporary art to review the canons of sculpture (North, 1992). In one of the examples, a destroyed fountain was recreated in a negative form as a well. In another, nothing is constructed; passersby activate the projection of a text that reminds them what the location was used for during the war. In the third example, a column was mounted on which the public could make inscriptions, adding their names to those of people killed by Nazism; after the lower portion of the column was filled up, a mechanism allowed submerging it, making space available for more inscriptions; until the column disppeared, leaving only a mark on the ground (Young, 1992). ${ }^{2}$

Despite these experiments, the forms questioned by the counter-monuments continue to be built. For example, in Brazil, where large religious statues have recently been constructed. Based on a survey conducted on the internet that is far from exhaustive, going back only to the year 2000, I identified 10 statues portraying Christian personalities, each more than 30 meters tall. These monuments were built in cities in different regions of the country, and some of them are on hills, which makes them highly visible. The globally famous statue of Christ the Redeemer, inaugurated in 1931, which is 38 meters tall, serves as a model for some of these new monuments, while some of them sought to exceed the size of the original. ${ }^{3}$ The others are of Catholic saints and priests.

1 This article is part of the results from the project, "Religião, cultura e espaços públicos" (Religion, Culture, and Public Spaces), sponsored by a CNPq (National Scientific and Technological Development Council) productivity grant. The text was elaborated during a Post-doctoral period in the Free University of Amsterdam. I appreciate the comments from Mattijs Van de Port, Birgit Meyer, Martijn Oosterbaan, Dan Beekers, Carlos Steil, and Rodrigo Toniol. Translation by Jeffrey Hoff.

2 Miles (1997) prefers the category "anti-monuments" to designate similar forms.

3 A 2004 survey found 185 statutes of various proportions that are copies of or inspired directly by Christ the Redeemer of Rio de Janeiro. See Giumbelli (2014), a group of studies that anticipate some of the ideas developed in this text. 
This text looks at the case of the monument of Saint Paulina, for which construction began in 2016 in the city of Imbituba in southern Brazil. The statue is designed to be 46-meters tall and will be located on a hilltop around which grew the municipality that now has 40 thousand residents. Saint Paulina is the name by which Amábile Lucia Visintainer (1865-1942) became known when she was canonized in 2002. The official sanctuary of the saint is in the city of Nova Trento, where she spent most of her life, although she was born in Italy. Imbituba, which is $200 \mathrm{~km}$ to the South, is the site of what was recognized by the Vatican as the first miracle attributed to Paulina. The idea of a monument arose in the late 1990s, suggested by an association of pilgrims, and gained strength 10 years later with the engagement of municipal and state authorities and the release of budgetary resources. A design competition was held in 2010. The Sanctuary of Saint Paulina supports the monument's construction. The Imbituba municipal government affirms that the project will be good for the economy, counting on the fact that "religious tourism" will generate employment and bring visitors to Imbituba.

I will explore some aspects of the controversies that this monument has been generating and some characteristics that its architectural forms have acquired. The analysis that I propose below is based on the idea of "public spaces" and one objective of this text is to contribute to the theoretical debate about this idea. The point is not to offer a conceptual definition for this idea, which could raise the expectation of a justification that would demonstrate its advantages in relation to congeneric formulations - "public sphere", "public domain", and of course, the singular "public space". I explore another possibility, without failing to consider some of the debates that these formulations have been raising since the 1990s. I propose to develop perspectives about two aspects of the idea of public spaces. One focuses on discourses that define something as "public". The other focuses on spatial dimensions: how material features influence configurations of public spaces. Each theoretical exploration corresponds to an analysis of certain facets of the Saint Paulina monument, respectively related to the debates that it has triggered and the architectural solutions it has generated. In the conclusions, I will point to possible continuations of the study that began in 2014. To begin, I will reflect briefly on the field of "public art" - which is related to the text by Young (1992) mentioned above. 
Discussions about public art are the main inspiration for the use that this text makes of the idea of public spaces. The idea is not to conduct a more or less exhaustive review of the extensive literature about concepts such as public sphere and public space - a task that others have undertaken. ${ }^{4}$ Debates about public art are interesting because they require us to address different facets of the existence of monuments, allowing a simultaneous focus on discourses and on material dimensions. A comparison with other monuments remains implicit in this text, as well as a look at many of the local actors directly involved with the construction of the image of Saint Paulina. Most of the data I explore here is available on the internet. I intend to present elements that are sufficient and suitable to allow contemplating the monument in Imbituba as a work of public art, even to consider possibilities that are suggested by counter-monuments. Composition and decomposition are not processes that are self-exclusive. To accept this idea, it is necessary to find leads in the way that certain discussions about public art reject the need for a definition.

\section{Public art: no single definition, but some leads}

What I would like to highlight in the discussion about public art refers to the difficulties in defining it. The expression arose in the 1960s and in less than 20 years was the subject of many debates. Miles (1997), who was involved in these debates, commented that public art is a term that seeks to designate a heterogeneous set of works: sculptures and performances in open spaces, community murals, land art, site-specific art, and even more specific work such as designs on pavements and street furniture. Defined in this way, public art is a term that allows connecting contemporary urban interventions with the monuments and memorials that are found scattered throughout Western metropolises, particularly since the late nineteenth century. As examples of "open spaces" in which works of art can be found Miles mentions: public squares, government properties, corporate plazas, parks and festivals, schools, hospitals, railroad

4 For the debate related to religion, see Meyer and Moors (2006), Meyer (2009) and Ferrari and Pastorelli (2012). 
stations, outer walls of buildings - some of which are spaces observed in the chapters of his book.

Thus, the place where a work of art is located can qualify it as public. The conventional space of galleries and of museums functions as a counterpoint for this definition of public art. This definition, however, has become the object of problematizations. Miles (1997) is only one of the authors who contribute to this problematization. For example, the fact that a place is open to the public does not mean that access to it is unlimited; even if it formally is, it does not mean that it is welcoming to all and any person. This discussion is related with criticisms aimed at aesthetic projects - involving works of art - related to the privatization of public spaces or to gentrification of residential areas. Thus, a criteria to be considered for the definition of public art would be its financing, which should be from the state (or generated by representatives who are not tied to corporate interests). But this means reconsidering the exclusion of museums and cultural centers, many of which are directly tied to the state or approved to receive its resources. Another factor considered to establish what is public art consists in the evaluation of its social relevance. But an analysis of the criteria for this relevance - considering the involvement of particular communities in the production of works or on their capacity to attract spectators with a broad scope of social profiles - indicates that the ground once again is not solid.

A collection of essays edited by Mitchell (1992a, p. 4) offers us a valuable resource to deepen this problematization about public art. Its objective is to "rethink the conceptual and physical locations of art and its possible publics", stimulating a discussion about certain works of art and about the possible meanings of "public". One example is the contribution of the editor himself, who sought to break with common definitions of public art. Commenting on controversies that arose over works that use religious objects, even when exposed in galleries, the author concludes that "the privacy of the exhibition site is no longer a protection for art that does symbolic violence to revered public figures or to public emblems and icons" (Mitchell, 1992b, p. 32). From this perspective, any art could be potentially public. Another provocation is made by North's (1992) text, which reflects on certain characteristics of contemporary sculptures. Something recurrent in them is the expectation of the beholders' participation. This applies to the three works commented on by Young (1992) and mentioned above: respectively the body that leans over the well, the body that activates the projection 
of a video, the body that inscribes something on the column. The same holds for the conclusion that North $(1992$, p. 25) reaches: these "works place their viewers in a public space that is articulated in terms of political controversy so that to view the piece is not simply to experience space but also to enter a debate".

We perceive how this discussion tends to add a discursive dimension to the concrete elements that define something as public art. Two other texts point in this direction. Phillips argues that a truly public art is that which, wherever it is, contributes to debate the conditions of a common life. In his words: "a truly public art will derive its 'publicness' not from its location, but from the nature of its engagement with the congested, cacophonous intersections of personal interests, collective values, social issues, political events, and wider cultural patterns that mark out our civic life" (Phillips 2000, p. 192). Deutsche (1992, p. 39) comes to similar conclusions, proposing that public art is not that which occupies certain spaces or interacts with certain publics, but "a practice that constitutes a public by engaging people in political debate".

It is not by chance that the two last paragraphs end with the same word: debate. This confirms the redistribution of criteria for evaluating the "publicness" of the art, with the emphasis on more abstract dimensions. This, however, need not signify the annulment of the material dimensions that all works of art carry. Most of the texts mentioned above are dedicated to commenting on - and eulogizing - specific artworks. North (1992) emphasizes artistic installations that not only inspire debate, but have debate as their theme. In the examples he offers, the dematerialization of the work of art goes together with the artistic materialization of the debate. In any case, the discussion about public art inspires an exploration about the idea of public spaces that embraces both dimensions, one that is more discursive and another that is more material, suggesting the intertwined tracks that this article will follow. First, it is worth considering a valuable point in Deutsche's (1992) text, which is not disassociated from these routes. Although it suggests what public art should be, this proposal depends on an idea of public that rejects definitions that are extrinsic or prior to concrete situations. These situations, according to the author, are constituted by the participation of socially situated subjects who interact not only by means of discourses, but also by means of their senses. Thus, what defines public space are "the relations structuring vision [and other senses] and discourses themselves" (Deutsche, 1992, p. 44). 


\section{The discursive constitution of what is public}

Formulations like those of Deutsche (1992) point to one of the routes taken in the debate about the Habermasian concept of the "public sphere". With this concept, Habermas sought to locate the historic constitution of a field of political deliberation in modernity, and to suggest its decline. Since the early 1990s, critics have contributed to keeping in vogue the debate and the concept around which it developed. A series of analytical investments - focused in the past or in the present - question a normative understanding of the Habermasian concept, above all when it is linked to a certain ideal of democracy. It is thus noted how the use of the notion of the public sphere has been accompanying a lament about the lack of compliance of its demands. ${ }^{5}$ In reaction to this, an effort is made to empirically characterize the ways by which something is constituted as "public", problematizing the conditions needed for this constitution. These conditions apply both to the actors who are apt to participate in the arena considered to be public, and to the instruments and realms recognized as valid in the field of a debate. ${ }^{6}$ In this way, the idea of public space is redimensioned - and pluralized - considering its analytical potential.

The theme of religion occupies an important place in this redimensioning. One reason for this is that the Habermasian formulation about the historic constitution of the public sphere does not confer a place to religion. It is thus an ally of the modern narrative that associates religion to the "private". On this plane, Habermasian philosophy converges with the place that liberal conceptions confer to religion. ' It is above all beyond the European framework that the limitations of these perspectives are more clear. The theoretical contributions that characterize works like that by Meyer (2011) - about Ghana - and Hirschkind (2001) - about Egypt - benefit from empiric situations that show the presence of religion in public spaces and its importance for the definition

5 See McKee (2004) for a recent example of this normative understanding about "public sphere".

6 See Meyer and Moors (2006), Meyer (2011), Benhabib (1992), Fraser (1992), Asad (2003), Hirschkind (2001), Englund (2011).

7 It is not by chance that both Habermas as well as liberal theorists feel pressured to review their positions about the status of religion, recurring to the idea of the post-secular. For a criticism of this idea for the study of religion, see Beckford (2012). 
of what is the public sphere. In Brazil, where theses of secularization were received with criticism, scholars are also considering the concept of public space. Burity (2016) discusses the relationship between religion and politics inspired by plural concepts of democracy. Birman (2017), based on anthropological perspectives about state actions, analyzes public events in which religious agents and concepts gain importance. Montero $(2015,2016)$, although she begins with Habermas, incorporates references from pragmatic French sociology that lead her to formulate the idea of "dynamics of publicness". Thus, she proposes the study of controversies in which religious elements are involved to understand how the public space itself is constituted.

The conclusion reached by Meyer and Moors (2006, p. 12) deserves to be repeated here: "Rather than employing the notion of a united public sphere, some have argued that it is more productive to imagine it as a proliferation of publics, as a contested terrain that ought to be thought of in terms of its multiplicity or diversity". In addition to the references cited above in this section, the discussion about public art - with its questions about ideas of public and about publics as audiences - is particularly valuable for producing these effects. What is sought, therefore, is not precisely a new concept, in the substantive sense, to substitute Habermasian or liberal concepts. The question, above all, is to use the idea of public spaces in a way that allows it to capture the diversity of meanings and forms with which the public is constituted. Along with this, it is essential to create possibilities by which the constitution of the public would be accessible by means of distinct paths, given that its definition cannot be established prior to the processes of its composition. With this perspective, I believe it would be useful to develop the idea of public spaces in three dimensions that seek to account for these processes of composition, maintaining the emphasis on the discursive dimension, which is the mark (as well as limit) of the Habermasian formulation. This development - achieved by a kind of modulation of the term "public" - intends to influence the analysis presented in the section below.

The first dimension is that of publicness. Public here designates that which is an issue of common concern (Fraser, 1992). In other formulations that I consider to be equivalent, public relates to the definition of common problems (Bader, 2012) and to relevance in the framework of some debate (Engelke, 2013). Going public is how Meyer (2011) prefers to refer to this dimension. These 
conceptualizations make clear that the refusal to make an apriori definition of what is public does not mean that the term looses the capacity to grasp important and influential processes. However, to do so, as the comment by Benhabib (1992) makes clear, public cannot be associated to a special type of activity or to a substantive content. As Fraser (1992) shows, even the opposition to the "private" must be understood in its specific meanings and its pertinence evaluated. Publicness fundamentally depends on the production of visibility. This is what Montero $(2015,2016)$ proposes, because upon asking about that which is public we are led to analyze the processes by which certain themes become the object of debate, together with definitions about what can be said and about what goes without saying. Therefore, to make visible is to make controversial (Latour, 2005), as will be demonstrated in the case of the debate about the monument of Saint Paulina.

The second dimension is that of publicity. This involves the processes by which something becomes public. That is, upon accompanying the debate, the forms by which it is developed cannot be ignored. The ideas, on their own, are not sufficient for characterizing these debates. Engelke (2013) develops this point by showing how Christian propagandists who he studied reflect on the language that they need to use to reach "the person on the street". From this reflection result both billboards as well as beer mats on which messages are presented. Meanwhile, in Egypt, cassette tapes were found to be good media for the dissemination of Islamic sermons (Hirschkind, 2001), while in Ghana films are the scenario and the instrument of combat that the Pentecostals use against the traditional beliefs (Meyer, 2015). The situation that I follow in Brazil has as a protagonist a monument, and in the section "A monument in space" I will show how the monument seeks, through its material conditions, to establish itself as public. In the next section, I consider the fact that the monument was an object of journalistic coverage. This coverage allowed the expression of arguments that are not tied to the local context and that help - not without producing risks - to fulfill the very objective of the monument: to conquer publicity.

The third dimension is that of the addressed publics. This is a specific reference to Warner (2002) and its reflections in other works (Engelke, 2013; Meyer; Moors, 2006; Moors; Sahli, 2009). According to Warner (2002, p. 54), "publics do not exist apart from the discourse that addresses them". Inserted in a broad 
concept of discourse, articulated to a performative approach about language, this formulation involves a construction of collectivities that is distinct from that of groups with "saturated identities". A public does not need to be a group with this characteristic; it need only point to a universe of undefined frontiers, which can be mobilized by a certain discourse. Thus, it is not difficult to imagine how different publics can coexist. More than coexist, these publics define themselves relationally: "Any position is reflexive, not only asserting itself, but also characterizing its relation to other positions up to limits that compass the imagined scene of circulation" (Warner, 2002, p. 63). More than conviviality, there is a dispute: "Some publics [...] are more likely than others to stand in for the public, to frame their address as the universal discussion of the people." (Warner, 2002, p. 84). My aim in the following section is to identify some of the publics that affirm themselves by means of the debate around the monument of Saint Paulina and seek to indicate how the discourse that supports the construction of the statue redimensions the terms in which the controversy takes place.

\section{A monument in debate}

There was probably never a moment in which the announcement of the construction of a monument to homage Saint Paulinha in Imbituba has not stirred controversies. I will highlight and emphasize an element that is quite particular to this controversy. It is part of the coverage and repercussion of a journalistic article that was presented in 2016 by a leading national online news site (Giovanaz, 2016). ${ }^{8}$ Why have I chosen this report and the debate that it stirred? The arguments that we observe in the national controversy also circulate at the local level, as I found in my conversations in Imbituba. However, what is most important is that this controversy allows perceiving the problems that are raised by the construction of a religious monument in general - or that is, from a perspective not linked to the local context, but that does not fail to have impacts on it. The publics that are mobilized in the repercussion of the journalistic article are not those directly related to the monument project. They are

8 The article was published on UOL Notícias, which is hosted by one of Brazil's leading online media portals. 
publics whose existence is explained by the debates that involve religion in Brazil and that can only be visualized by the intervention of a highly accessed online news site. Thus, the news also constitutes the publicness of the monument by means of the electronic media (publicity), raising a debate that reveals publics that the promoters of the work must consider.

In her study in Ghana, Meyer (2011) observes how religion is part of the public sphere: a fundamental element of political disputes that is spectacularly exhibited in the electronic media. This presence in the public sphere, far from being peaceful, triggers protests by social sectors that do not agree with the place conquered by religion. Although the situation in Brazil is quite different, there is a similarity: the recent growth in the number of Evangelicals and of their visibility, with outstanding expressions in politics and the media, is accompanied by a debate about their legitimacy. ${ }^{9}$ The result is the coexistence, in public debates, of religious arguments and criticisms of religion. It is also necessary to consider the importance conquered in recent years by the issue of secularism. Although since the late nineteenth century the Brazilian state is constitutionally secular, relations in various dimensions between the state and religious agents and forces were and continue to be common. The rise of the Evangelicals and their presence in politics and media have reinforced discourses that call for stricter application of secularist principles. These elements, as we will see, appear in the reactions to the journalistic report published about the monument to Saint Paulina.

The journalistic article is entitled "Municipal Government in SC [Santa Catarina state, where Imbituba is located] builds religious statue larger than Christ the Redeemer" and was published at the time when the construction of the monument to Saint Paulina was beginning in June 2016. The title suggests the huge size of the statue and the state financing of its costs. Various characteristics of the project and of the work are presented, with statements from a representative of the municipal government and of the president of an association of pilgrims. There are two images, one of the molds for the statue and another of the design for the monument. Another statement is from a resident

9 For an overview of the religious changes in Brazil, see Birman and Leite (2000). For a discussion about religion and public spaces that considers the situation in Southern Europe, see Blanes and Mapril (2013). 
of Imbituba, on which the following passage is based: "Since the launching ceremony, the project has faced the rejection of atheists, agnostics and members of Evangelical churches who do not feel represented by Saint Paulina." The end of the article highlights official data about "religious tourism" in Brazil, noting that after it is concluded, the statue will enter "the list of the three largest religious sculptures in Brazil" (Giovanaz, 2016). The article received 180 comments on the site where it was published. ${ }^{10}$

A statistic from the records demonstrates that most of the comments involve religiously based criticisms of the monument (36) and reactions to these criticisms (70): which together account for about $60 \%$ of the total. The religiously based criticisms invariably invoke a traditional theme that opposes Evangelicals and Catholics in Brazil, the accusation of idolatry. For example: "Regardless of religion, [...] for those who use the sacred Bible in general as a base of faith and doctrine, God said the following: 'You will not make for yourself an image in sculpture' [...] what part of the people do not understand this writing, my God!!![?]". That is, the monument that portrays Saint Paulina is condemned for the same reasons that allow a Protestant to reject the Catholic practice of the worship of saints and their images. Another example: "it is for this reason that Brazil is this misery of a country. [...] people prefer to please a pile of clay, cement, plaster and metal [than] please God all powerful, the creator of everything!". These criticisms show the strength of religious arguments in public debates, which is related with the protagonism of the Evangelicals in Brazil. We can also say that this discourse seeks to constitute an anti-idolatry public.

This discourse provoked various reactions. One of them is the Catholic response that disputes the Biblical argument or points out how far back images have been worshipped in Christianity. For example: "In relation to what is being said that we Catholics worship images, this is not true. Since the beginning of Christianity Christians have painted sacred images. The Bible

10 Some of the comments generate a succession of responses and counter responses. 180 is the total number of initial comments, responses and counter responses. The length of each comment varies: including one of up to 15 lines, although most are no longer than five lines. The identification of the commentators was not considered in the analysis. All of the transcriptions in this section are from this group of comments, which is available at Giovanaz (2016). See Engelke (2013, p. 49) for a similar use of this kind of material, which is related to the discussion about circularity by Warner (2002). 
prohibits idol worship, because there was polytheism. Our images are not of gods and we do not worship them, but we honor and venerate them." The comment continues, noting that "in the same book of Exodus in which God prohibited making idols, he ordered the making of sacred images of cherubs". Another response is a counter-attack of the Evangelicals, evoking criticisms of some of their churches and leaders that are well disseminated in Brazil: "It is better to have statues that represent God and his representatives than people who identify themselves as pastors 'taking' money from the fools and becoming millionaires at their cost". The commentary suggests that "mansions and big cars" are worshipped as idols by these pastors, which is much worse than worshipping statues. Thus, the religious criticism of the monument can raise a social criticism of the religious.

Another response to the religious criticism is a generalized criticism of religions. For example: "Of course there are no miracles. We live in a reality of cause and effect. In Africa and in Syria, millions of children are killed by hunger and by wars and no 'miracle' is saving them. Meanwhile, according to certain brilliant minds, God or Jesus is 'curing' [...] in the churches. It's a pure lie!!!". The criticism of the miracle is in keeping with a discourse - at times made in the name of atheism - which seeks to decrease the public role of religion, as the same comment demonstrates: "The mayor of this city should be jailed immediately simply for the idea of spending money on this 'saint'." Finally, and perhaps as a general reaction to the responses presented, there are comments that lament that religion is the motivation of conflicts. For example: "I believe that the Bible is the word of God and I understand that each person one day will answer to Him, but who am I to judge the attitudes of someone given that each religion sees faith through a different window?" In this case, the reference to the monument disappears in favor of the principle that "salvation is individual". That is, even when it is a question of relativizing religion, the argument continues to be articulated in religious terms.

We now come to a second block of comments that also have statistical relevance. This second block includes registers that evoke the theme of secularism (27) and the responses to them (17), which together account for about $25 \%$ of the total. In various comments, the principle of secularity of the state appears to question any support to religion. Therefore, we can say that this discourse seeks to constitute a pro-secular public. For example: "Does the state have extra money 
to invest in a religious statue? Isn't the state secular? Why is it then spending money on a religious statue? Is it that this municipality has money to spend on this even though not all Brazilians are Catholic? Perhaps they should make a statue of Buddha for the Buddhists?". Based on the characterization of the statue as Catholic, the state would not be able to finance it to maintain observance of the principle of religious equality. In reaction to this, there are comments that question the understanding of what is secular. One of them affirms that "Secular state [...] means being [...] tolerant with all religions, that is, all worship will be accepted". Another points out the paroxysm of secularism, which without the proper understanding, would require changing the name of cities with Catholic references or destroying the famous Christ the Redeemer statue.

Although the argument addressed to the pro-secular public aims to delegitimize construction of the monument, it raises a debate about the very idea of secularism. This is well illustrated by a chain of responses and counterresponses to the following comment: "Spend everyone's money on a statue that only represents a portion of the population: what happened to the secular state?" One response recalled that obelisks were installed in various places, perhaps to suggest that they may have a religious meaning. Another laments that there is no real secularism in Brazil, as shown by the programming of a TV network whose owner is a Pentecostal leader. One comment seeks to clarify that "A secular state is not atheist", supported by another who affirms: "Secular state means: do not interfere in anyone's religion". To which one person, intending to support the initial position, responded: "in a secular state, atheists are also respected". And the debate continued, with new invocations of secularism as a limiting principle ("Evangelicals and non-Christians pay for the Catholics to have a religious symbol, under the pretext of being a tourist attraction?") and, as a counterpoint, arguments that seek to limit these impediments ("secular state means that we can worship any religion, or none at all. The construction of the statue may be valid [...] as an investment"; "if its purpose is to generate tourism for this city, everyone can win").

The observation of the comments, with their responses and counterresponses, shows a chain of arguments that take many directions. If the paragraph above presents a summary of this chain beginning with a comment that evokes secularism in a strict sense, the same can be realized based on one of the many reactions that attacks idolatry with biblical arguments. 
This multidirectionality of the comments, with the accompanying cacophony, alludes to the characteristics of the debates that run through public spaces themselves - if we agree not to portray them from a normative point of view. When I propose the organization of the comments in two blocks, that of antiidolatry and that of pro-secularity, it is so that we can perceive some points on which the arguments converge. In their initial intention, both discourses aim to present reasons that criticize the construction of the monument. They are reasons that the municipal government of Imbituba - through its representatives - must consider to continue the project.

The position taken by the municipal government is aligned to a third block of arguments, whose presence is also significant (approximately $35 \%$ of the registers) among the comments about the report of June 2016. Forty-two comments criticize the construction of the monument because the writers believe that better use should be made of public money. This criticism may be associated with pro-secular or anti-idolatry arguments. But this is not necessary, as seen by this example: "Money thrown in the garbage!!! I would like to know if this municipality of 40 thousand residents has sewerage collection that is $100 \%$ treated, streets properly paved, a functioning hospital with proper infrastructure, quality education, suitably equipped police, without any other outstanding problem!!!" Another 15 comments counter this kind of argument, justifying the construction of the monument. I highlight two, the first because it is presented by someone who identifies himself as a "resident of Imbituba": "the city really needs a strong tourist attraction. [...] For people who think it's bad, wait for [the statue] to be ready and come visit. We know that it is a Catholic monument, but the merchants and hotel network that will be benefited by the tourists are of various religions. Everyone will win in the end." The second because it reinforces the publicity that the news - and the debate - confer to the monument: "If [the work] is well promoted and well planned, it can generate income for many people within a city that until today many people have never heard of!".

The terms by which these discourses defend the construction of the monument are also present in the reasons invoked by the Imbituba municipal government and by the residents who support it. Its website promotes a news article from 2015 in which these reasons appear: “"The mayor affirmed that the work will be for everyone. 'It is a project for the development of the city, 
because it will stimulate tourism and the economy, in the first years it will generate 500 to 1,000 jobs and new businesses." ${ }^{11}$. The field of "religious tourism" serves as a more general reference to highlight arguments about the economic advantages of the project. These arguments do not reject the religious connotation of the monument, but seek to attenuate it by using terms such as "ecumenical", "Christian" and "spiritual". ${ }^{12}$ They seek, even if implicitly, to counter the discourses that mobilize the anti-idolatry and pro-secular publics, who have other definitions of "religion". ${ }^{13}$ Instead of these publics, the municipal government is investing in a discourse that is addressed to "all", to designate those benefitted by the monument, whether "all" the residents of the city, or "all" the visitors to the tourist attraction.

Warner (2002) suggested that certain publics attain the conditions to present themselves without the need for justifications or specifications, in relation to which counter-publics are constituted. In the debate about the Saint Paulina monument, both the anti-idolatry and pro-secular groups appear, in fact, to be configured as counter-publics. But perhaps the discourse that points to the economic gains that will benefit "all" does not go unquestioned. It is possible that even after construction of the monument, lack of secularity and excess of devotion will be constant threats to its success. In any case, by investing in "religious tourism" the municipal government - and the "all" that this discourse aspires to mobilize - has already produced a shift in the meaning related to the religious and to its presence in the public realm. The process is caught well in Montero's (2016, p. 140-141) formulation about the "dynamics of publicness": “[...] the actors not only pass through, connect and overlap abilities and repertoires that refer to distinct fields, but also continuously redesign and negotiate their borders when it involves defining the configurations of a public issue. And by doing so, change the very sense of what can be understood as religious.".

11 http://www.imbituba.sc.gov.br/noticias/com-decreto-ambiental-obra-de-monumento-e-lancada (accessed on 06/10/2015).

12 "Ecumenical" and "spiritual" are terms that appear in the discourse of the president of the pilgrims association mentioned in the report; "Christian" is how the monument is described in an ad of the municipal government.

13 Situations approached by Astor, Burchardt and Griera (2017) and by Oliphant (2015) also raise questions about changing meanings and definitions of religion. 


\section{The spatial constitution of the public}

An article published in 2010 by sociologist Kim Knott announced a "spatial shift in research about religion". In her theorization about how the concept of space would allow (re)articulating various aspects of religious life, an important point is captured by the following formulation: "No longer a mere theater for other action, it [space] is enmeshed in embodiment and practice, knowledge and discourse" (Knott, 2010, p. 37). This idea had been anticipated by Coleman and Collins (2006, p. 41) when they rejected observing religious locations as only "theologies fixed in space": "the building not merely contains, but is constitutive of religious practice". ${ }^{14}$ The affirmation would have the approval of Verkaaik (2012, p. 162), an anthropologist who studied the construction of mosques without reducing them to "mere objects of political-religious representations". This is one among many examples of how the "spatial turn" can also be perceived in anthropology, driven by various discussions, as modes of embodiment, theory of language, analysis of objects, a methodology with an emphasis on material dimensions, criticisms of the notion of representation, etc. The question is if this interest in space, which is developed particularly in relation to buildings, can be expanded for us to think about the notion of public spaces. That is, is it possible, in this syntagma, to confer a meaning that is not metaphorical to "space"?

Birgit Meyer (2011; Meyer; Moors, 2006) takes an important step in this direction. In her discussion of the Harbermasian line, she distinguishes her perspective by focusing on praxis and materiality "that explores how religious publics actually come into being through shared images, texts, sounds, and styles of binding" (Meyer, 2011, p. 153). This returns to the points I presented in relation to the idea of publicity. But now other elements must be added. The public sphere is not defined only by a debate of ideas, but involves aesthetic dimensions, in the sense proposed by Meyer (2009), who leads us to consider the sensational forms and the material aspects of the constitution of publics. With this inspiration, Verkaaik (2012, p. 162) seeks to understand what

14 Also see the collection of Hopkins, Kong and Olson (2013), which calls attention to the "co-production of religion and place across a range of contexts, scales, and networks". In Latin America, the work of Frigerio (2017) deserves attention. 
he designates as "the affective powers of images, sounds and texts". ${ }^{15}$ In sum, publics are constituted by means of dispositions and abilities that are articulated to specific sensational and material configurations. We do not participate in public spaces only by supporting arguments, but as bodies that act and are affected.

A valuable complement to this perspective can be found in the articles presented by Lossau and Stevens (2015), which reinforce an interest in a dialog with the discussion about public art. In this case, the reflection begins not from the notion of public, but from the concept of space. The organizers turn to the idea of affordances, which refers to the properties things have that make them usable in certain forms. Objects and spaces do not determine behaviors, but allow or facilitate certain actions, and limit and make others difficult. Stevens (2015) helps to develop this idea when he turns to the relationship between the physical characteristics of spaces (scale, surface, forms and materials) and the human body's dimensions and movements. This involves corporal abilities and senses (how to use something?), but also social interactions (who can use something?). In the latter aspect, Lofland (1998) points to illustrative situations - which dialog with the focus of other texts about public art (Miles, 1997). What effects does urban architecture have on social interactions? Are the streets of a city planned to facilitate or impede the encounter of residents? Although Lofland is basically interested in denouncing architectural solutions that destroy or sanitize public spaces, the perspective is compatible with that assumed in other chapters of Lossau and Stevens' book: perceive the space not only as "an impalpable and tacit socio-spatial context" but as something "concrete, meaningful and haptic" (Zebracki, 2015, p. 172).

Another valuable point of the book edited by Lossau and Stevens (2015) is that some of its chapters are dedicated to the study of monuments. ${ }^{16}$ Some analytical dimensions arise that should be mentioned, particularly because of their impact on how I will continue to discuss the case of Saint Paulina. The introduction to the book proposes a distinction between function and use, the first designating the intentions of an architectural design and the second

15 See Van de Port (2013) and Oosterbaan (2009) for analyses that are inspired by this perspective. For a study in Brazil that focuses on material dimensions, see Menezes (2011).

16 There is an extensive bibliography about monuments that is quite focused on issues of representation and memory. For other issues, with which this text dialogs, see the study by Sansi (2010). 
its actual use (Stevens; Lossau, 2015). However, it should be added, as shown by the study by Lees (2001), that designs can have ambiguities that will be related to diverse interpretations and uses. Other distinctions mobilize oppositions between symbolic uses and performative uses (Stevens; Lossau, 2015) and between symbol and prop (Franck, 2015). The value of these distinctions is that they allow articulating representational and pragmatic dimensions, a point that is also emphasized by Van der Hoorn (2009). As we will see below, both dimensions are important in our understanding of the spatial characteristics of the Saint Paulina monument.

Finally, it is worth indicating the analytical relevance of an important anthropological reference, the ideas of A. Gell, which I recalled when reflecting on a work by Gieryn (2002), who studied the conception and use of a science laboratory. Gieryn (2002, p. 42) affirms: "designers who sketch out material artifacts also create human users and even an entire society among which the machine or building can thrive", which allow us to see the design of any artifact as "a blueprint for human behavior and social structure". I suggest that what Gyerin calls users, society, social structure and human behavior - which in his analysis corresponds to various categories of scientists and students - is similar to what in this text appear as "publics". With this in mind, we consider a text by Gell (1996) about traps. Gell suggests that every trap is simultaneously a model of the hunter and a model of the prey. It acts in the place of the hunter and it captures the action of the prey. That is, all traps reveal something about their maker and project something about their prey. Gell proposes that works of art be studied in the same way. Why not imagine that this applies to a monument? How does the monument of Saint Paulina reveal something about the city that it intends to represent and project something about the public it intends to attract?

\section{A monument in space}

At the time this article was being written, the $3,000 \mathrm{~m}^{2}$ site where the monument will be located has acquired the shape of the project; the molds of the face and the hands of the statue are ready to receive the concrete that will materialize the saint. There is a video whose images, accompanied by contemplative 
music, animate the monument design..$^{17}$ The statue portraying Saint Paulina is located at one of the extremes of the site, to which flow two traffic circles that mark the access routes to the statue and establish the contours of a type of garden. The surroundings are covered by vegetation, in an area destined for "environmental preservation". There is no pedestal, and visitors can enter the base of the statue, which houses a large hall. The project was designed by Marcelo Francalacci, who attended various art schools and has made other monuments in southern Brazil towns. ${ }^{18}$ Francalacci says that his dedication to monuments was motivated by the idea of "removing artwork from the gallery" to approximate it to "people". These terms - which as we saw constitute one of the ways to define "public art" - can be inverted to ask about how his work tries to attract visitors.

We begin with the representation of the Catholic saint. The competition which Francalacci's design won required that the proposal have "symbolic appeal compatible with the history of Saint Paulina". ${ }^{19}$ In practice, this required referring to elements used in the images that portray the Saint, which are circulated by the congregation to which Saint Paulina belonged. Francalacci's monument is a composition of more or less realistic forms. Realist representations are present in decorative items (a bust and a panel that portrays the saint) and in the sculpture of the face and hands of the statue. But the artist describes the lines of the rest of the statue as "contemporary". It has a conical, nearly tubular form, with few details, in which stand out, in addition to stylized flowers, the face and hands. One of the hands is positioned as if it is giving a blessing; the other is holding an object described as a bible. A cross is visible on her mantle.

If we compare Francalacci's work with other representations of Saint Paulina, we can say that it is a new variation. The image that the president of the association of pilgrims of Imbituba refers to as the "official" image of St. Paulina includes a bible and a cross, as well as bread that is offered to a

17 Available at https://www.youtube.com/watch?v=AXx92tGbwjA (accessed on 18/01/2017).

18 The main source of the information about Francalacci is Dornelles (2016).

19 The instructions for projects can be found at http://www.imbituba.sc.gov.br/a-prefeitura/editais-de-licitacao/detalhes/12549 (accessed on 19/06/2016). 
child who is at the saint's feet. ${ }^{20}$ But the sanctuary of Saint Paulina presents as objects of devotion statues in which the saint appears without these elements - allowing her to open her arms - or in others - with a hoe to represent work in agriculture. ${ }^{21}$ Francalacci used only two of these objects. His main innovation is certainly in the "contemporary" traits, which create a stylized image. This solution did not go unnoticed by some of those who commented on the article in June 2016. Some of those who did not appreciate it say it looks like a large chess piece, a lighthouse or a phallic object. Although these terms intend to express aesthetic disapproval, it is more interesting that they associate the statue's forms to non-devotional elements. It can be said, therefore, that the design embodies an ambiguity between a religious image and non-devotional objects.

My analysis of the monument dialogs with Verkaaik's (2012) text about mosque construction. One point that Verkaaik's interpretation addresses is precisely the expectation that each mosque converses with an architectural tradition, which does not mean that innovations do not occur. "Religious tradition can in fact be interpreted in such a way that it becomes a critique of customary building styles" (Verkaaik, 2012, p. 164). But the mosques respond to other demands, like serving as spaces for non-religious activities while simultaneously creating an atmosphere suitable to devotion. These dimensions also appear in the prayer room at an airport whose design is analyzed by Kraftl and Adey (2008). In this case, the challenge was to conceive an environment that would produce a sense of relaxation, hospitality and permanence amid the bustle of the surrounding space. These feelings occupy an important place in the reading that Tamimi Arab (2013) proposes of a mosque, which is simultaneously an object of anxiety and pride due to its relation with the city and the surrounding society. Thus one question that the architecture should respond to is: "How can a building evoke feelings of toleration and sentiments of sociability?" (Tamimi Arab, 2013, p. 59).

20 An image with these characteristics can be seen here: http://lojasnsp.com.br/imagem-santapaulina-32-cm.html\# (accessed on 19/01/2017).

21 Images from the sanctuary can be seen here: http://santuariosantapaulina.org.br/index.php/osantuario/recantos (accessed on 18/01/2017). 
Francalacci also uses emotional and sensorial language to describe his design, ${ }^{22}$ which corresponds to his understanding that: "Art has the power to stir people's emotions and make them think". Commenting on the conception of the saint's face, he adds another dimension to the more apparent realistic and figurative dimension: "I prefer to work with a young, idealized face, and not only in reproducing the face. I portrayed the spirit of Saint Paulina, to express a sweet, affectionate gaze". Reinforcing the argument that economic gains are the main motivation for the monument, the artist does not fail to add that his objective is to "calm the hearts of people who visit". Finally, upon describing the effects of light that can be noted with the solution adopted for the lighting of the hall inside the statue, Francalacci promises: "The tourist who enters will be astonished by the work." The artist's words do not need to be taken as descriptions or prescriptions, but can be clues for us to perceive some tensions that are triggered by the monument's spatial configurations.

We begin with the place that promises to produce astonishment, which is at the inside of the statue. Francalacci adopted elements that he had used at another monument of the Virgin Mary, which has a conical form and a chapel within it. The dimensions of the monument and the chapel make them seem to be one..$^{23}$ In the monument of Saint Paulina, despite following the same formula, the result is different. The interior space is much smaller than the statue. More importantly: it is not designed to be a chapel. There is no altar and the panels that are planned should tell the history of Saint Paulina and her miracles. Significantly, if at times this space is referred to as a "chapel", at other times it is designated as a place for "meditation" and even as a "museum". ${ }^{24}$ In the video animation about the project, although there is contemplative music, the people who appear inside the statue are not worshipping, but appear to be reading the panels and speaking about the information (which promises to be in various languages). It is for this public - worshipers-tourists - that the lighting effects seek to bring astonishment.

22 For the quotes, see Dornelles (2016).

23 For images of this monument, see http://aguatur.tur.br/nossa-senhora-aparecida-itaipulandia-pr/ (accessed on 15/02/2017).

24 See https://www.youtube.com/watch?v=Xpv1_ZPP4-4; https://www.youtube.com/ watch?v=aoTt-j5rF6I (accessed on 19/01/2017); Giovanaz (2016). 
On the outside, the video about the project shows more people, once again with no one seen to be worshipping: they are walking and talking, appearing to enjoy the location, which has benches and paths. The images do not describe the few structures that are planned for the outside area. Francalacci mentions "bathrooms, stores and a security post". This list had been larger, having included a pharmacy and "other conveniences"; even a "panoramic restaurant" was considered. ${ }^{25}$ The facilities planned for the top of the mountain have been reduced with the hope that tourists will use services in other parts of the city. The tranquility enjoyed by the visitors to the monument cannot keep them on top of the mountain. They must be attracted and redirected to be consumers in the city.

There is, therefore, a tension between the monument and the city, which is expressed in another characteristic of its architecture. If the orientations of the design are followed, the statue will have its back turned to the center of Imbituba. To compensate, something is planned that is not highlighted in the video about the project, an observation space, which would overlook the heart of the city and the stunning landscape of the sea, lagoons and forested mountains. This composition between the monument and the lookout reveals crucial tensions. The video suggests that the statue dominates the surrounding landscape. Visibility is one of the demands that the project seeks to respond to, promising that the statue will be seen, day and night, from a distance of many kilometers. ${ }^{26}$ This is one of the ways to capture the attention of those who are traveling at the edge of the city. Upon reaching the monument, however, the visitor won't be absorbed by its structures or invited to submerge in its forms. ${ }^{27}$ Instead of being captivated by the sweet gaze of the saint, the visitors can be carried away by the stunning landscape. The architectural composition has

25 See http://www.sc.gov.br/index.php/component/content/article?id=17\&idGNG=40165\&pgListG ng=318\&Itemid $=$ (accessed on 19/01/2017).

26 Although with a very different solution, visibility is also a demand in the case of the mosque studied by Beekers and Tamimi Arab (2016), whose discussion about iconicity was inspiring to this text. Monuments located in squares, streets and beaches establish another relationship with the landscape, as a comparison could demonstrate.

27 One example of these alternative possibilities is the Holocaust Memorial located in Berlin, with its nearly 3,000 blocks separated by spaces in which people can walk (Stevens, 2015). 
a strong dialog with the landscape, but oscillates between being a mark in this landscape and a lens; between a point to look at or from which to look.

"Ambient faith" is how Engelke (2013) designates the result of a project proposed by a Christian institution in an English town. On Christmas season, one of the shopping centers in the city was decorated with kites that represent angels. This was how - simultaneously inconspicuous and generically attractive - these Christians intended to mark the space of the city. The subtlety with which they did so provoked Engelke to use the idea of ambient music as a pertinent metaphor. Chambers (2006) uses the idea of a flag to capture the subtlety with which Christian temples survive in a Welsh town, even without receiving the faithful or acquiring historic recognition. In Imbituba, it is not a heritage from the past, but a new monument that seeks to inhabit the landscape. If it does not have the lightness of the kite-angels, subtlety does not fail to be an issue. First, because the conical form produces a new aesthetic for the saint, approximating her to secular objects. Second, because it is not as worshipers that her visitors are imagined. It pretends to capture them as observers, whether of the monument, or of the landscape. At the same time, the intention is for the place to be only a point of passage to reach the city. Finally, because the result that the monument seeks depends on the conjugation of opposing elements: the monument is religious, visitors need not be. It seeks to attract them without converting them.

\section{Final considerations}

The purpose of the conception and approach used in the two discussions about public space in this text was to pluralize each one of the terms that form this syntagma. Thus, on one hand, the category "public" can be conjugated in the three dimensions captured by the analysis of discourses: that which registers what becomes relevant, that of the means that produce this relevance and that of the collectives that are addressed. On the other hand, the category "spaces" requires an analysis that is focused on material dimensions and sensational formations. This dual perspective was based on texts about public art and the data about the monument of Saint Paulina. We followed a debate that addresses diverse publics and was triggered by an article on a widely read 
internet news site and that established the work as something important in the discussion about the place of religion in Brazil. The analysis of some elements of the design and construction of the monument sought to point to some tensions, considering on one hand, the relationship with the city and the landscape and on the other, the visitors that the municipality hopes to attract. With the continuity of the study, one priority will be to understand the local debates, considering the spaces in which they take place. That is, what in this text was separated into two sections could be, on another occasion, articulated under the idea of spatialized discourses.

Despite some criticisms, the work of the monument advances. Once completed, the 46-meter tall concrete statue could conspicuously inhabit the landscape for a considerable period. In a book he dedicated to considering the effect of time on buildings Brand (1994) begins with the principle that all must adapt to the uses that they wind up serving. But he makes an exception for monuments, which are supposedly immune to time (Brand, 1994, p. 2). Meanwhile, Loussau and Stevens (2015), although they join Coleman and Collins (2006) to agree with Brand about the analytical priority to the concept of use, include various monuments in their book. Perhaps the monument at Saint Paulina is - or will come to be - an example of what Van der Hoorn (2009) studied, undesirable constructions. Always threatened with destruction or forgetting, these constructions do not fail to have an important role in the life of the cities that they inhabit. Based on what we can foresee in the present, working basically with elements of the design for the project, I sought to explore what Lees (2001) indicates as the ambiguity of intention (also exemplified in the study by Franck, 2015). This ambiguity is expressed in the forms of the Imbituba monument, with the possibilities that they offer for it to become a natural park (both a part of the landscape and a point for observing the landscape), as a visiting point that pays homage to a religious woman without needing to worship her, as well as a sanctuary recognized and venerated by her devotees.

Finally the monument can be many things, even that which is now indescribable, which would result if it is not concluded. At the same time, as part of public spaces, the monument has already produced some realities. If my analysis about the debates stirred by the news report are correct, we can affirm that the monument is sustained by a discourse that counters two publics who aim to delegitimize the work; either because they understand it commits the sin 
of idolatry, or because it is a crime against secularism. This is a discourse that promises to serve "all" by constructing a sense of religious that intends to be immune to both accusations. A similar shift of meaning is also achieved by the subtlety that the enormous statue employs to associate it to a Catholic saint. Its peculiar forms allow that it be assimilated to non-devotional objects. The spatial dispositions of the elements of the project suggest that its visitors do not need to convert to approach the feet of the saint. It is with these characteristics that the monument to Saint Paulina participates in the constitution of public spaces. And insofar it stirs debates about themes such as the place of religion in society and that it links its success to the ability to attract and refract people, it invites us to consider it - whether we like it or not - as public art.

\section{References}

ASAD, T. Secularism, nation-state, religion. In: ASAD, T. Formations of the secular: Christianity, Islam, modernity. Stanford: Stanford University Press, 2003. p. 181-201.

ASTOR, A.; BURCHARDT, M.; GRIERA, M. The politics of religious heritage: framing claims to religion as culture in Spain. Journal for the Scientific Study of Religion, v. 56, n. 1, p. 126-142, 2017.

BADER, V. The 'public-private' divide on drift: what, if any, is its importance for analysing limits of associational religious freedoms?. In: FERRARI, S.; PASTORELLI, S. (Ed.). Religion in public spaces: a European perspective. London: Ashgate, 2012. p. 47-70.

BECKFORD, J. Public religions and the postsecular: critical reflections. Journal for the Scientific Study of Religion, v. 51, n. 1, p. 1-15, 2012.

BEEKERS, D.; TAMIMI ARAB, P. Dreams of an iconic mosque: spatial and temporal entanglements of a converted church in Amsterdam. Material Religion, v. 12, n. 2, p. 137-164, 2016.

BENHABIB, S. Models of public space: Hannah Arendt, the liberal tradition, and Jurgen Habermas. In: CALHOUN, C. (Ed.). Habermas and the public sphere. Cambridge: MIT Press, 1992. p. 73-98.

BIRMAN, P. Governing the poor: secular and religious practices in debate. In: MAPRIL, J. et al. (Ed.). Secularisms in a postsecular age?: religiosities and subjectivities in comparative perspective. Cham: Palgrave Macmillan, 2017. p. 187-206. 
BIRMAN, P.; LEITE, M. Whatever happened to what used to be the largest Catholic country in the world?. Daedalus, v. 129, n. 2, p. 271-290, 2000.

BLANES, R.; MAPRIL, J. (Ed.). Sites and politics of religious diversity in Southern Europe. Leiden: Brill, 2013.

BRAND, S. How buildings learn: what happens after they're built. New York: Penguin Books, 1994.

BURITY, J. Minoritization and pluralization: what is the 'people' that Pentecostal politicization is building?. Latin American Perspectives, v. 43, n. 3, p. 116-132, 2016.

CHAMBERS, P. Sacred landscapes, redundant chapels and carpet warehouses: the religious heritage of South West Wales. In: ARWECK, E.; KEENAN, W. (Ed.). Materializing religion: expression, performance and ritual. Aldershot: Ashgate, 2006. p. 21-31.

COLEMAN, S.; COLLINS, P. The shape of faith or the architectural forms of the religious life. In: ARWECK, E.; KEENAN, W. (Ed.). Materializing religion: expression, performance and ritual. Aldershot: Ashgate, 2006. p. 32-44.

DEUTSCHE, R. Art and public space: questions of democracy. Social Text, n. 33, p. 34-53, 1992.

DORNELLES, T. Santa pelas mãos de um tubaronense. Diário do Sul, 18 jun. 2016. Available at: <http://diariodosul.com.br/SITE2015/noticia/25891/Santa-pelasmaos-de-um-tubaronense.html>. Accessed: 18 Jan. 2017.

ENGELKE, M. God's agents: biblical publicity in contemporary England. Berkeley: University of California Press, 2013.

ENGLUND, H. Introduction. In: ENGLUND, H. (Ed.). Christianity and public culture in Africa. Columbus: Ohio University Press, 2011. p. 1-24.

FERRARI, S.; PASTORELLI, S. (Ed.). Religion in public spaces: a European perspective. London: Ashgate, 2012.

FRANCK, K. As prop and symbol engaging with works of art in public space. In: LOSSAU, J.; STEVENS, Q. (Ed.). The uses of art in public space. New York: Routledge, 2015. p. 183-200.

FRASER, N. Rethinking the public sphere: a contribution to the critique of actually existing democracy. In: CALHOUN, C. (Ed.). Habermas and the public sphere. Cambridge: MIT Press, 1992. p. 109-142.

FRIGERIO, A. Religion out of place: social regulation of evangelical expansion in Buenos Aires. In: MAPRIL, J. et al. (Ed.). Secularisms in a postsecular age?: religiosities and subjectivities in comparative perspective. Cham: Palgrave Macmillan, 2017. p. 275-293. 
GELL, A. Vogel's net: traps as artworks and artworks as traps. Journal of Material Culture, v. 1, n. 1, p. 15-38, 1996.

GIERYN, T. F. What buildings do. Theory and Society, v. 31, n. 1, p. 35-74, 2002.

GIOVANAZ, D. Prefeitura em SC constrói estátua religiosa maior que o Cristo Redentor. UOL Notícias, 3 jun. 2016. Available at: <http://noticias.uol.com.br/cotidiano/ ultimas-noticias/2016/06/03/santa-catarina-constroi-estatua-religiosa-maiorque-o-cristo-redentor.htm>. Accessed: 20 Sept. 2017.

GIUMBELLI, E. Símbolos religiosos em controvérsias. São Paulo: Terceiro Nome, 2014.

HIRSCHKIND, C. Civic virtue and religious reason: an Islamic counterpublic. Cultural Anthropology, v. 16, n. 1, p. 3-34, 2001.

HOPKINS, P.; KONG, L.; OLSON, E. (Ed.). Religion and place. Dordrecht: Springer, 2013.

KNOTT, K. Religion, space, and place: the spatial turn in research on religion. Religion and Society: Advances in Research, v. 1, p. 29-43, 2010.

KRAFTL, P.; ADEY, P. Architecture/affect/inhabitation: geographies of being-in buildings. Annals of the Association of American Geographers, v. 98, n. 1, p. 213-231, 2008.

LATOUR, B. From Realpolitik to Dingpolitik - or how to make things public. In: LATOUR, B.; WEIBEL, P. (Ed.). Making things public: atmospheres of democracy. Cambridge: MIT Press, 2005. p. 14-41.

LEES, L. Towards a critical geography of architecture: the case of an ersatz Colosseum. Ecumene, v. 8, n. 1, p. 51-86, 2001.

LOFLAND, L. The public realm: exploring the city's quintessential social territory. New York: Aldine de Gruyter, 1998.

LOSSAU, J.; STEVENS, Q. (Ed.). The uses of art in public space. New York: Routledge, 2015.

McKEE, A. The public sphere: an introduction. Cambridge: Cambridge University Press, 2004.

MENEZES, R. de C. A imagem sagrada na era da reprodutibilidade técnica: sobre santinhos. Horizontes Antropológicos, Porto Alegre, ano 17, n. 36, p. 43-65, jul./dez. 2011.

MEYER, B. Introduction. In: MEYER, B. (Ed.). Aesthetic formations: media, religion, and the senses. New York: Palgrave, 2009. p. 1-28.

MEYER, B. Going and making public. Some reflections on Pentecostalism as public religion in Ghana. In: ENGLUND, H. (Ed.). Christianity and public culture in Africa. Columbus: Ohio University Press, 2011. p. 149-166. 
MEYER, B. Sensational movies: video, vision and Christianity in Ghana. Berkeley: University of California Press, 2015.

MEYER, B.; MOORS, A. Introduction. In: MEYER, B.; MOORS, A. (Ed.). Religion, media, and the public sphere. Bloomington: Indiana University Press, 2006. p. 1-25.

MILES, M. Art, space and the city: public art and urban futures. London: Routledge, 1997.

MITCHELL, W. J. T. (Ed.). Art and the public sphere. Chicago: University of Chicago Press, 1992a.

MITCHELL, W. J. T. The violence of public art: do the right thing. In: MITCHELL, W. J. T. (Ed.). Art and the public sphere. Chicago: University of Chicago Press, 1992b. p. 32-55.

MONTERO, P. Introdução. In: MONTERO, P. (Org.). Religiões e controvérsias públicas: experiências, práticas sociais e discursos. São Paulo: Terceiro Nome: Ed. Unicamp, 2015. p. 11-25.

MONTERO, P. “Religiões públicas” ou religiões na esfera pública? Para uma crítica ao conceito de campo religioso de Pierre Bourdieu. Religião e Sociedade, Rio de Janeiro, v. 36, n. 1, p. 128-150, 2016.

MOORS, A.; SALIH, R. 'Muslim women' in Europe: secular normativities, bodily performances and multiple publics. Social Anthropology, v. 17, n. 4, p. 375-378, 2009.

NORTH, M. The public as sculpture: from heavenly city to mass ornament. MITCHELL, W. J. T. (Ed.). Art and the public sphere. Chicago: University of Chicago Press, 1992. p. 56-72.

OLIPHANT, E. Beyond blasphemy or devotion: art, the secular, and Catholicism in Paris. Journal of the Royal Anthropological Institute, v. 21, n. 2, p. 352-373, 2015.

OOSTERBAAN, M. Sonic supremacy: sound, space and the politics of presence in a favela in Rio de Janeiro. Critique of Anthropology, v. 29, n. 1, p. 81-104, 2009.

PHILLIPS, P. Out of order. In: MILES, M.; HALL, T.; BORDEN, I. (Ed.). The city cultures reader. London: Routledge, 2000. p. 190-196.

SANSI, R. Fetishes and monuments: Afro-Brazilian art and culture in the 20th Century. New York: Berghahn, 2010.

STEVENS, Q.; LOSSAU, J. Framing art and its uses in public space. In: LOSSAU, J.; STEVENS, Q. (Ed.). The uses of art in public space. New York: Routledge, 2015. p. 2-16.

STEVENS, Q. The ergonomics of public art. In: LOSSAU, J.; STEVENS, Q. (Ed.). The uses of art in public space. New York: Routledge, 2015. p. 20-32. 
TAMIMI ARAB, P. The biggest mosque in Europe! A symmetrical anthropology of Islamic architecture in Rotterdam. In: VERKAAIK, O. (Ed.). Religious architecture: anthropological perspectives. Amsterdam: Amsterdam University Press, 2013. p. 47-62.

VAN de PORT, M. Golden storm. The ecstasy of the Igreja de São Francisco, Salvador da Bahia, Brazil. In: VERKAAIK, O. (Ed.). Religious architecture: anthropological perspectives. Amsterdam: Amsterdam University Press, 2013. p. 63-82.

VAN der HOORN, M. Indispensable eyesores: an anthropology of undesired buildings. New York: Berghahn, 2009.

VERKAAIK, O. Designing the 'anti-mosque': identity, religion and affect in contemporary European mosque design. Social Anthropology, v. 20, n. 2, p. 161-176, 2012.

WARNER, M. Publics and counterpublics. Public Culture, v. 14, n. 1, p. 49-90, 2002.

YOUNG, J. E. The counter-monument: memory against itself in Germany today. In: MITCHELL, W. J. T. (Ed.). Art and the public sphere. Chicago: University of Chicago Press, 1992. p. 73-90.

ZEBRACKI, M. Art engagers. What does public art do to its publics? The case of the 'Butt Plug Gnome'. In: LOSSAU, J.; STEVENS, Q. (Ed.). The uses of art in public space. New York: Routledge, 2015. p. 167-182.

Recebido: 29/09/2017 Aceito: 11/05/2018 | Received: 9/29/2017 Accepted:5/11/2018 